\title{
STRUCTURES IN ICE CLIFFS AT THE SNOUTS OF THREE SWISS GLACIERS
}

\author{
By Michael J. Hambrey* \\ (Geographisches Institut und Geologisches Institut, Eidg. Technische Hochschule, 8og2 \\ Zürich, Switzerland)
}

\begin{abstract}
Anstract. Three glaciers in Switzerland, Griesgletscher, Oberaargletscher and Vadrec da l'Albigna, terminate in lakes recently impounded for hydro-electricity generation. Calving at their snouts has produced excellent cross-sections which enable one to study the structures along almost complete vertical profiles when the lakes are empty. Each of the glacier cliffs displays a shallow synclinal structure which, by comparison with surface structures, is interpreted as the vertical expression of an arcuate foliation, originating in or below an ice fall or an area of transverse crevassing. Extensive minor folding of an earlier layering is associated with this foliation. Well-developed longitudinal foliation exposed at the surface is sometimes visible in these vertical sections, indicating that the structure can form at depth.

RÉsumé Structures dans les fronts de trois glaciers suisses. Trois glaciers suisses se terminent dans les lacs de retenne d'usines hydro-électriques construits récemment (Glaciers d'Oberaar, de Gries et de l'Albigna). Le vêlage de leur front a produit d'excellentes coupes transversales, qui permettent d'étudier les structures le long de profils verticaux presque complets lorsque le niveau des lacs est abaissé. Chaque falaise de glace laisse apparaître une structure synclinale de faible profondeur qui, par comparaison aux structures de surface, peuvent être interprétées comme étant l'expression verticale d'une foliation arquée prenant naissance soit au-dessous d'une chute de séracs, soit dans une zone de crevasses transversales. Associé à cette foliation on trouve un plissage répandu d'une foliation préexistant. Une foliation verticale longitudinale, que l'on trouve bien développée à la surface, s'observe parfois dans ces coupes verticales, indiquant que cette structure peut se former en profondeur.

Zusammenfassung. Strukturen in den Eiswänden von Gletscher zungen dreier Schweizer Gletscher. Drei Gletscher in der Schweiz, nämlich Gries-, Oberaar- und Albignagletscher, münden in Stauseen, die in neuerer Zeit angelegt worden sind. Es entstanden so durch Kalben vorzügliche Querprofile, an denen man bei tiefem Wasserstand die Strukturen im Eis an beinahe saigeren, Schnitten untersuchen kann. In allen drei Fällen zeigt sich in diesen Eiswänden eine seichte Synklinalstruktur, welche als Vertikalschnitt desjenigen Phänomens gedeutet werden kann, das auf der Oberfläche der Gletscher als Bogenlamininierung ("arcuate foliation") bezeichnet wird und unterhalb eines Eisfalles oder einer Zone intensiver Querspaltenbildung entsteht. Diese Laminierung ist begleitet von einer verbreiteten Kleinfältelung, welche eine ältere Bänderung überprägt. Weiter beobachtet man in diesem Querprofil zuweilen die auf der Oberfläche gut entwickelte Longitudinallaminierung, was darauf hinweist, dass diese Struktur in der Tiefe entstehen kann.
\end{abstract}

\section{INTRODUCTION}

The surface structures of temperate valley glaciers, in particular foliations, are fairly well documented, as a result of several detailed studies in recent years (e.g. Allen and others, i 960 ; Meier, I96o; Taylor, I962; Rutter, I965; Lliboutry, I964-65, Tom. 2, p. 612-I4; Ragan, I969; Anderton, 1973), although some problems of interpretation remain. In contrast, few observations in vertical sections have been made; most three-dimensional studies have been confined to the walls of crevasses or to where calving into the sea or into natural lakes has occurred. To determine whether structures such as foliations and minor folds pervade the whole mass of a glacier, or to what degree they maintain a constant orientation, it is useful to have a three-dimensional view of the structures.

A unique opportunity for a three-dimensional examination of glacier structures has arisen following the recent impounding of a number of lakes for hydro-electric purposes in Switzerland, as a result of which a number of glaciers now terminate in water. Three of them (Griesgletscher, Nufenenpass, Valais; Oberaargletscher, Grimselpass, Canton Bern; Vadrec da l'Albigna, Val Bregaglia, Grisons) provide almost complete vertical cross-sections, in which the structures are clearly displayed as a result of calving into the lakes at high water in late summer. During the winter the lakes are emptied, so that by early summer the complete sections stand clear of the water and thus are easily accessible.

* Present address: Department of Geology, Sedgwick Museum, Cambridge $\mathrm{CB}_{2}{ }_{3} \mathrm{EQ}$, England. 
In this paper the structures in the vertical sections in each of the three glaciers are described and compared with the structures observed at the surface. Some orientation measurements of structures in the cliff sections were made, but detailed examinations were not undertaken because of the danger of falling rocks and ice. However, some idea of orientations and structural relations could also be obtained by viewing from various angles and examining ice boulders at the foot of the cliffs.

\section{Griesgletscher}

Griesgletscher is the best known of the three glaciers studied, as a detailed study of deformation is at present being carried out. This glacier is $5 \mathrm{~km}$ long, has a small ice fall half-way along, and terminates in a cliff $375 \mathrm{~m}$ wide and nearly $50 \mathrm{~m}$ high (Fig. I). At low water the lower quarter to one-third of the cliff usually is obscured by fallen ice blocks and snow, but the remainder clearly shows an asymmetric synclinal structure (Fig. 2a), made up of discontinuous layers of coarse bubbly ice and lesser amounts of coarse clear and fine-grained ice (definitions of ice types according to Allen and others ( 1960$)$ ). Near the north margin (Fig. $2 \mathrm{a}$, right) the layering is parallel to the valley side, dipping towards the centre at about $45^{\circ}$. The dip increases to $70^{\circ}$ a short distance from the margin, and this is followed by a fairly abrupt decrease, the layers becoming gently dipping up-glacier in the centre of the glacier, where they crop out as horizontal bands in the cliff. Towards the south margin, the structure becomes weak and the ice is rather homogeneous, but the layering again is strongly developed at the margin; here it is parallel to a mass of debris-covered stagnant ice (Fig. I).

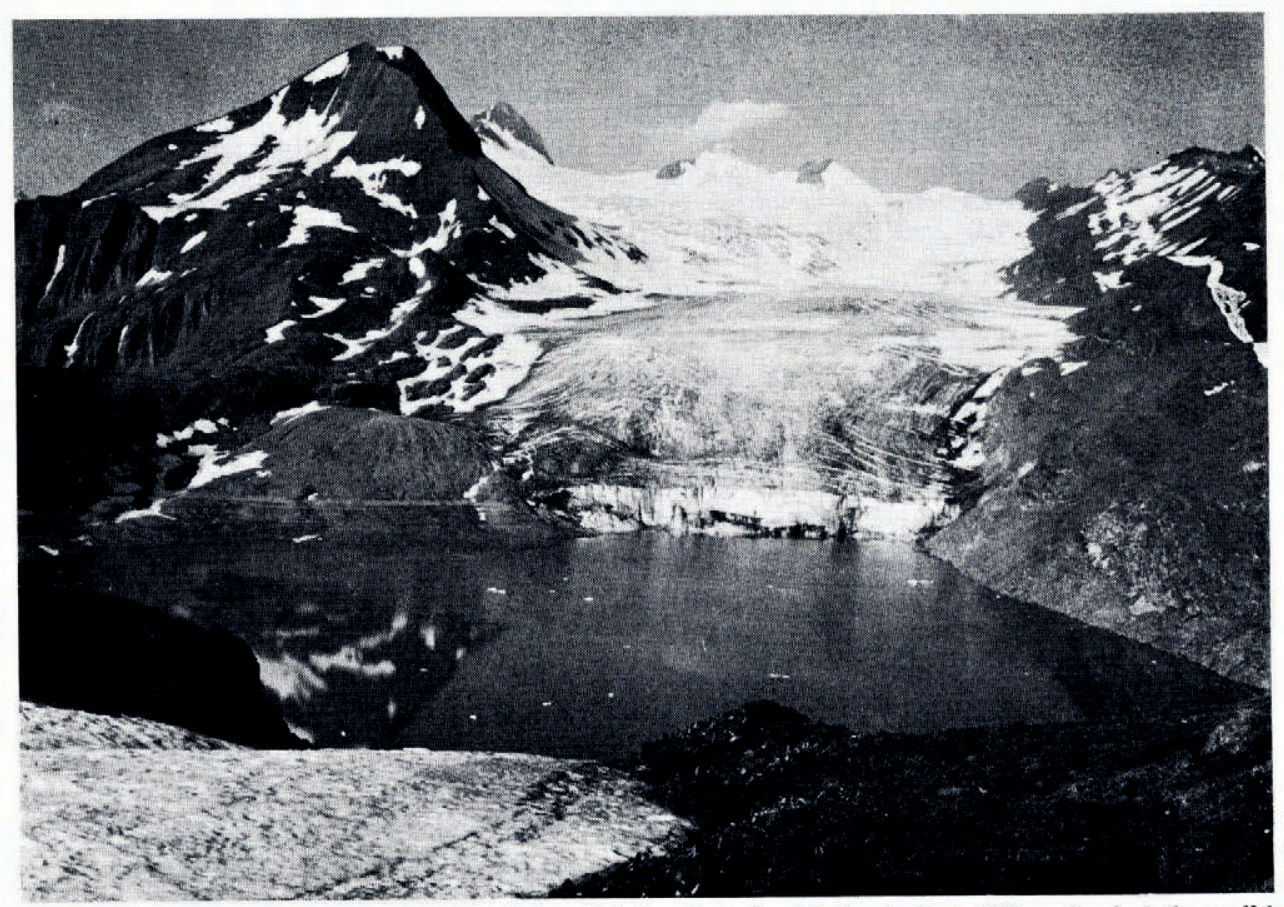

Fig. I. Griesgletscher, I August 1974. In the background, below the peak with the cloud cap (Blinnenhorn), is the small ice fall where an arcuate foliation is produced. The ice to the north (orographic left) of the ice fall is relatively inactive and does not reach the snout. The ice at the north end of the cliff originates near the left-hand side of the ice fall; this is confirmed by the fow lines obtained from velocity data. The dark streaks in the lower part of the ice cliff are debris-rich zones, aligned parallel to the arcuate foliation. The moraine-covered mass to the orographic right of the ice cliff is a mass of stagnant ice, effectively separate from the glacier. 


\section{(a) GRIESGLETSCHER}

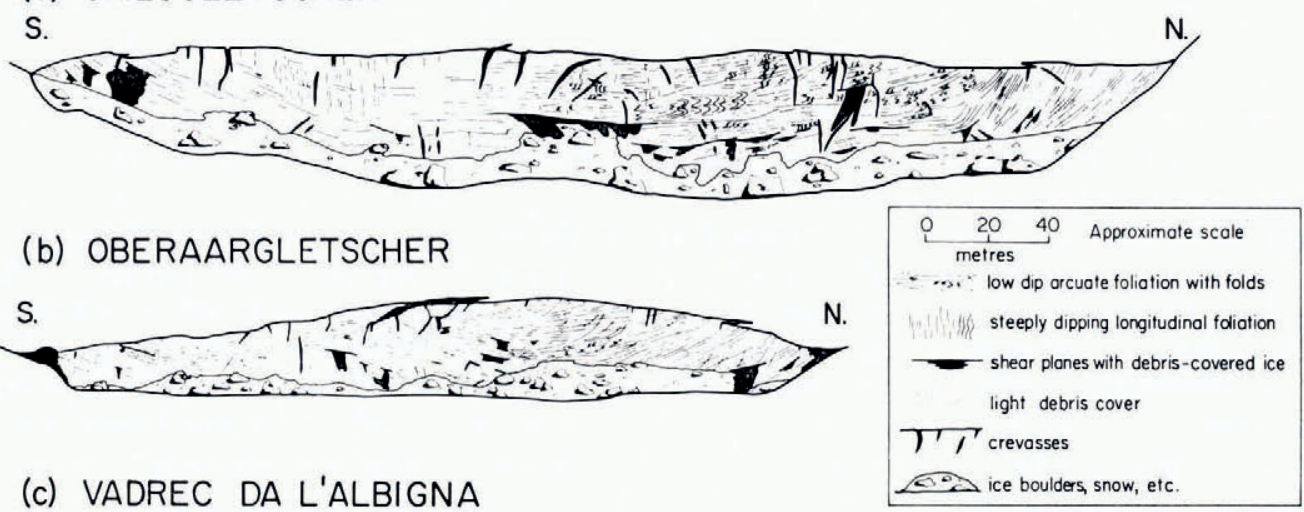

W.

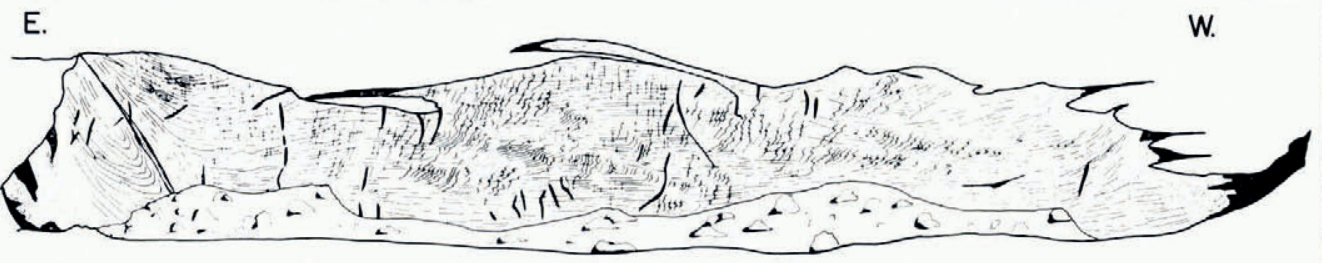

Fig. 2. Structures in the cliff sections of Griesgletscher (II July 1974), Oberaargletscher (28 June 1974) and Vadrec da l'Albigna (3 July 1974), drawn from telephotographs taken approximately normal to the cliffs at distances of about 1, o. 6 and $1 . I \mathrm{~km}$ respectively. Some small-scale detail has been added from close-up photographs.

Associated with the dominant layering are similar and isoclinal minor folds, having an amplitude of the order of o. I to I $\mathrm{m}$ (Fig. 2a). The folds are cut by, and their axial planes are parallel to, the layering; thus the layering can be regarded as an axial-plane foliation. The folds are best developed in the north-central part of the cliff. Several debris-bearing planes and thin layers of debris-rich ice near the base of the glacier are parallel to the layers of the main synclinal structure (Figs I and 2a). These may represent narrow zones in which the ice has the greatest tendency to deform or fracture by shear; they appear to correspond to a set of slip lines under longitudinal compression (Nye, I952, p. 88). If fracture occurs, debris-laden basal ice may override ice immediately down-glacier, enabling debris to be incorporated into the glacier internally. The fact that ice above the debris-rich zones in places overhangs the ice below by more than I m may indicate slip along a discrete plane, although this could also be accounted for by differential ablation between clean and dirty ice. Alternatively, the dirty ice could represent debris-rich crevasse traces; however, there is no indication at the surface of such features having the necessary orientation, and which have been able to rotate into a near-horizontal attitude (i.e. into the planes of the arcuate foliation). In any case there is little surface debris, and few crevasses would contain sufficient debris to produce such prominent features in the cliff. Also weakly developed in the cliff is a vertical longitudinal foliation, but this is easily overlooked and in much of the cliff it is not visible at all. Close examination of the cliff reveals little except a lineation of air bubbles parallel to this foliation, although from surface observations (in crevasses) it clearly is a three-dimensional feature. Unlike the other layers, it is not significantly enhanced by differential weathering of ice types. 
The surface structural pattern is rather complex, but the main features are illustrated in Figure 3. The most obvious structure is an arcuate foliation which originates in the ice fall. It remains approximately parallel to the long axis of the cumulative ("finite") strain ellipse during its evolution below the ice fall (Hambrey, 1977), although there is evidence, in the form of fine-grained ice, that the structure is a shear phenomenon. The mean dip of the layering initially is vertical; during flow a progressively decreasing up-glacier dip develops, as one would expect from the normal velocity profile in a valley glacier. At the snout the dip at the apices of the arcs has declined to around $10-15^{\circ}$, and the structure is rather faint, as it cuts the surface at a low angle. Minor folds, in alternating layers of clear and bubbly ice, are well developed, their axial planes lying approximately parallel to the arcuate foliation, both in the centre and at the margins of the glacier (some examples are illustrated in Hambrey (1977, fig. 5)). An earlier longitudinal foliation, when traced down-glacier, undergoes largescale distortion, which in part results from compression acting in a roughly longitudinal direction below the ice fall, and at the same time it becomes folded on a small scale (Fig. 3). The progressive deformation of this early foliation and the roughly contemporaneous development of the arcuate foliation can clearly be seen in large-scale aerial photographs. Possible boudinage structures (cf. Hambrey and Milnes, 1975) are widespread where the foliation has a longitudinal trend at the margins, and are orientated approximately parallel to the long axes of the cumulative strain ellipse in the most highly deformed ice. Similar structures have previously been attributed to the plastic collapse of abandoned moulins (e.g. Taylor, I962, p. 56), but in the Swiss glaciers they occur in regions of the greatest cumulative strain, as in rocks, often where there is little evidence of moulin activity. They have not been observed on Griesgletscher in areas of low cumulative strain, even though moulins are often found there. The arcuate foliation, with the associated minor folds, can be traced down-glacier to the snout, and clearly is the same structure as that which has the synclinal disposition in the cliff.

Numerous other structures, such as foliations and crevasse traces, intersect the main arcuate foliation. Of these, a late, weak, irregular, vertical longitudinal foliation, distinguishable, as are the other structures, by differential weathering of ice types, is the most important.

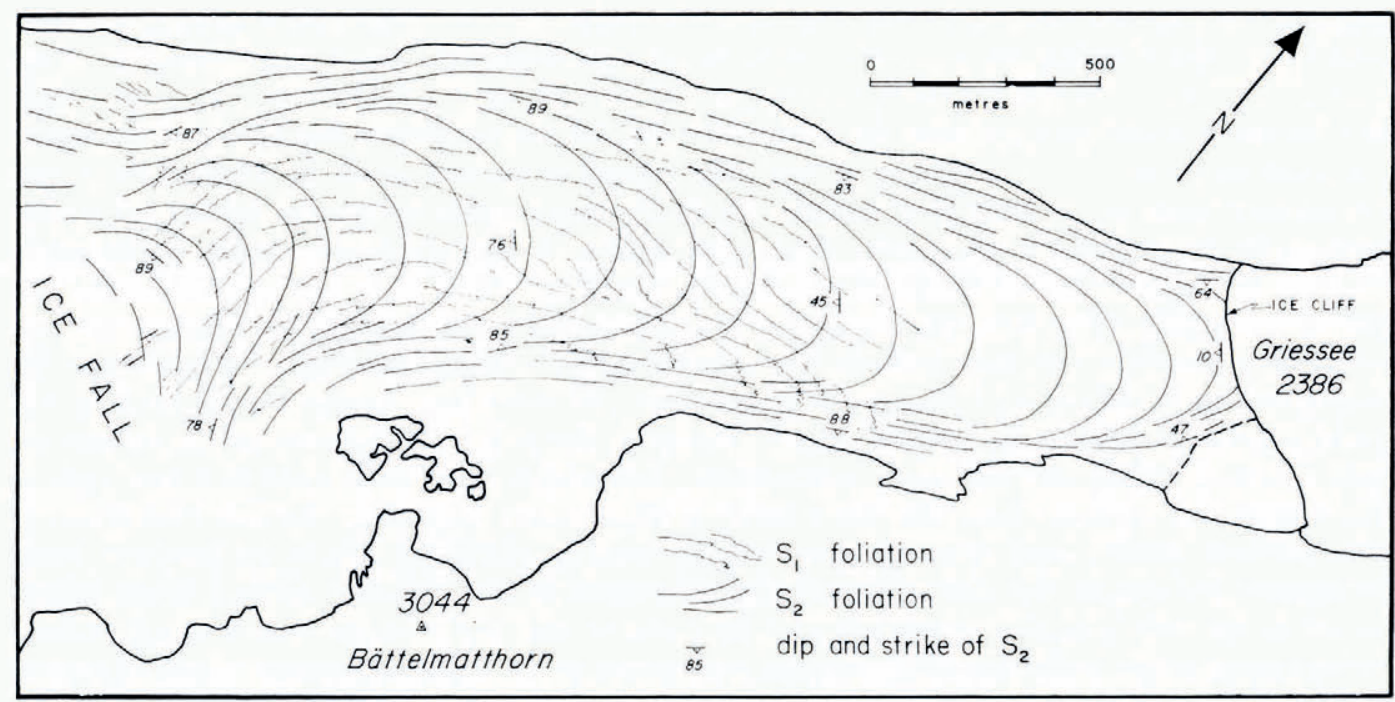

Fig. 3. Structures at the surface of Griesgletscher, illustrating the relationship between an early longitudinal foliation $\left(S_{1}\right)$ and tive arcuate foliation $\left(S_{2}\right)$. The $S_{1}$ becomes folded on the small scale, with axial planes developing parallel to $S_{2}$, in the area below the ice fall. 
This is sporadically visible throughout the width of the glacier and appears, from orientation measurements, to be the same vertical structure as that weakly developed in the cliff.

\section{OberaArgletscher}

The $5 \mathrm{~km}$ long, fairly straight, evenly graded Oberaargletscher terminates in a cliff about $35 \mathrm{~m}$ high and $280 \mathrm{~m}$ wide (Fig. 4). As Figure $2 \mathrm{~b}$ illustrates, the overall structure is simple, the layering having a synclinal disposition like that of Griesgletscher. The layering is a sequence of coarse bubbly ice with lesser amounts of coarse clear and fine-grained ice. Individual layers cannot normally be traced for more than about $50 \mathrm{~m}$. Near the margins, the layers are orientated parallel to the bedrock and thus have a dip of $30-50^{\circ}$. In the centre, where they crop out as horizontal bands, the dip is about $10^{\circ}$ up-glacier. In detail the picture is more complex in that minor folds are associated with the layered structure, especially in the centre of the cliff. Most of the folds are isoclinal or similar (tight folds), the axial planes of which are approximately parallel to the gross layering; they are best observed where they consist of fine-grained ice. Debris-rich layers, similar to those in Griesgletscher, are developed parallel to the synclinal structure in localized situations (Fig. 2b).

Numerous measurements of the surface structures were made on cross-profiles close to the snout and in the lower $2 \mathrm{~km}$ of the glacier. The pattern is rather complex, with many layers (foliations, debris-rich layers and crevasse traces) intersecting one another, but the dominant structure is a longitudinal foliation (Fig. 4). Near the snout this structure is parallel to the bedrock at the north margin, i.e. it dips at about $50^{\circ}$ towards the centre of the glacier. Here the foliation is associated with minor folds and boudinage-like structures, the axes of which are parallel to the foliation. In this region it is approximately parallel to the structure observed

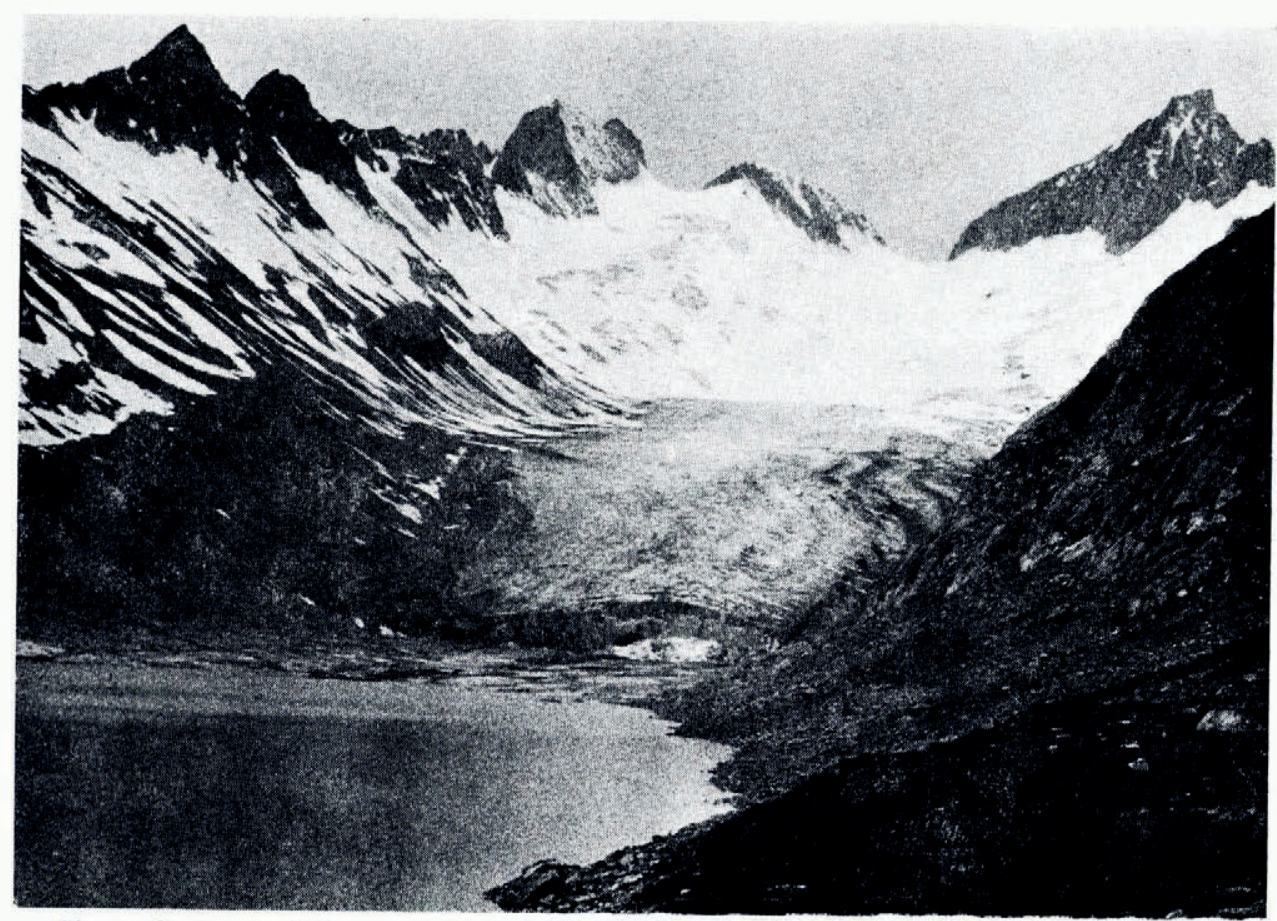

Fig. 4. Oberaargletscher, 30 Fuly 1974, with its ice cliff at low water. The main structure at the surface, a longitudinal foliation, is parallel to the medial moraines. The synclinal structure in the cliff (see Fig. $2 b$ and text) is believed to originate in a region of transverse crevasses just above the snow line. 
in the cliff (Fig. 2b, right). A gradual change to an almost vertical dip towards the opposite side of the glacier is apparent, although the structure is only weakly developed in mid-glacier. Obviously, the remainder of this foliation is not the same structure as that visible in the cliff, because in the middle of the glacier it would otherwise have a transverse trend at the surface. On higher profiles, in addition to the longitudinal foliation, one finds an irregular, weakly developed arcuate layering in mid-glacier, dipping at $20-30^{\circ}$ up-glacier. As far as it can be traced laterally, it attains a longitudinal trend and a slightly increasing dip. It was not possible to trace this structure with certainty all the way to the snout, but it seems quite likely that it is the same structure as that observed in the cliff. The fact that it was not observed on the lowest profile does not necessarily imply its absence, rather that it has not become accentuated by differential weathering because of its low dip relative to the surface. Snow conditions were unfavourable when these observations were made, hence it was not possible to trace the transverse structure to its source. However, it is probable that, following the more detailed work on the similar structure in Griesgletscher and in the light of observations made on other Alpine glaciers, it is an arcuate foliation, formed in an area of extensive crevassing, $2.5 \mathrm{~km}$ from the snout. Further detailed measurements are, however, necessary to confirm this.

\section{VADREC DA L'Albigna}

This $4 \mathrm{~km}$ long glacier has the largest cliff of the three glaciers discussed here, measuring $425 \mathrm{~m}$ in width and about $65 \mathrm{~m}$ in height (Fig. 5). Although the glacier is of relatively simple shape, the structures displayed in the cliff are exceedingly complex, and may have resulted in part from the interaction of former tributary glaciers.

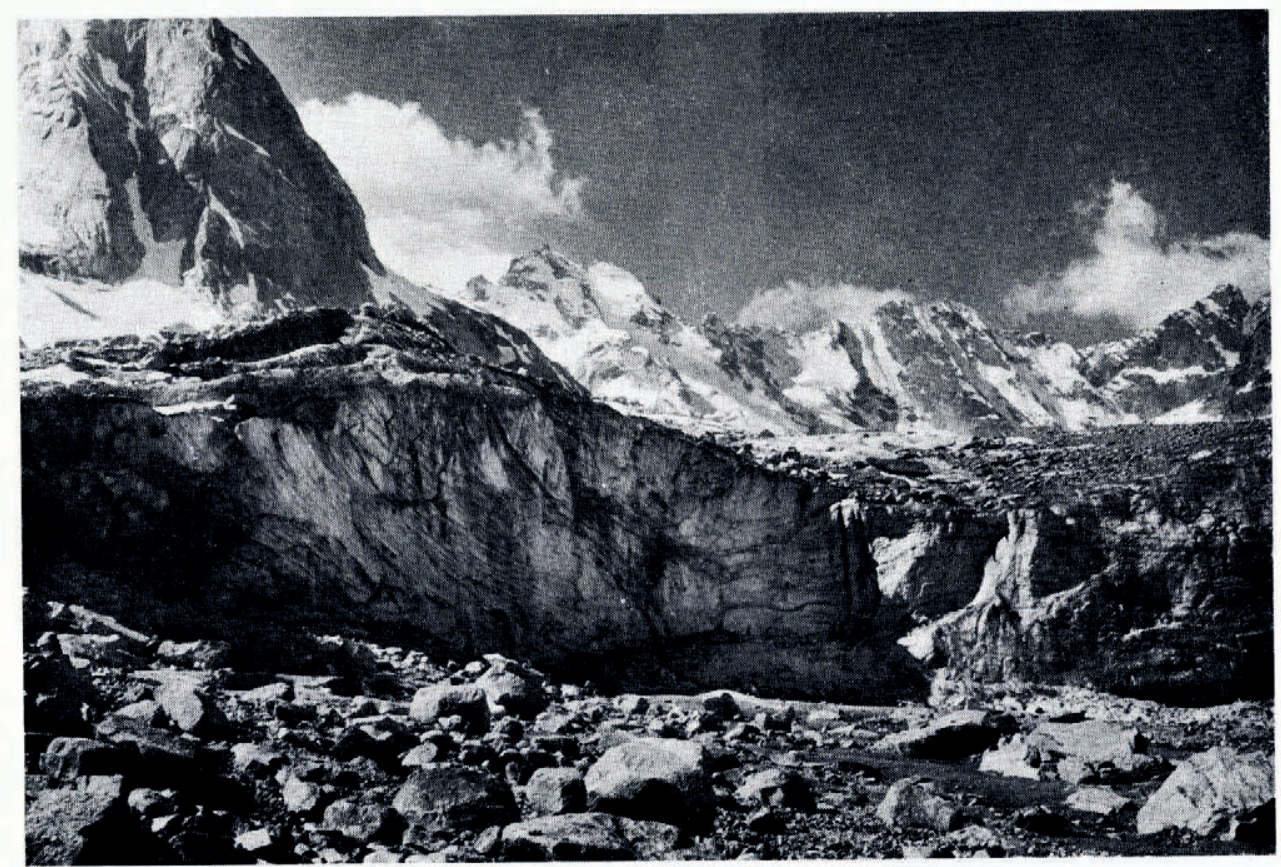

Fig. 5. The eastern half of the cliff of Vadrec da l'Albigna, 3 July 1974. To the left of the diagonal medial moraine in the cliff, lies the inclined major fold of a small flow unit. To the right is the main synclinal structure which extends to the west margin. Note also the intense folding in the cliff at the right of the picture. The highest part of the cliff illustrated here is about $60 \mathrm{~m}$ high. 
The cliff is slightly concave down-valley, and therefore the structures at the margins are foreshortened in Figure 2c. One large and two small flow units are distinguishable in the cliff; the latter lie side by side near the east margin, and are recognized by tight, large-scale folding of the layers (that closest to the margin is not shown in Figure 2c). One of these small flow units has an asymmetric, inclined folded structure (Figs 2c and 5), the lower limb of which is notable for the continuity of the layering, except for the development of weak boudinage-like structures. The fold axis is obliquely inclined with respect to the cliff. It is difficult to envisage what the layering originally represented, but it may have attained its present disposition by the superimposition of the main flow unit on the tributary. Separating this inclined fold from the main part of the glacier is a narrow medial moraine, which appears as a band of debris-rich ice cutting the cliff diagonally from top to bottom (Figs $2 \mathrm{C}$ and 5 ). The remainder of the glacier cliff reveals a simple, shallow synclinal structure consisting of discontinuous layers, similar to, but better developed than those of Griesgletscher and Oberaargletscher. Structures resembling foliation boudinage (cf. Hambrey and Milnes, 1975) are, in places, associated with this layering. Small-scale folding of a longitudinal foliation is visible in parts of the cliff, and indicates flattening approximately parallel to the layering, followed by rotation with respect to the incremental strain ellipses. The folding shows an interesting transition from east to west: at the eastern end of the large flow unit, the foliation essentially is vertical and undeformed (Fig. 2c). Tracing the structure west we find that it becomes slightly folded. Continuing west, the folding becomes increasingly intense and often is concentrated in narrow zones, while the overall dip of the foliation declines until, near the west margin, it is almost completely overturned and flattened in the planes of the other layers (Fig. 2c).

Good exposures of structures at the surface of Vadrec da l'Albigna are limited because of an extensive moraine cover, especially at the snout, and correlations with the structures in the cliff are difficult. The longitudinal foliation is well developed and fairly regular where observed, however, but the gently dipping layers of the synclinal structure are not easily recognized. Following the latter up-glacier as far as is possible, an increasing dip is apparent, but the surface outcrop is irregular until the dip has become $30-40^{\circ}$. Nevertheless, the most likely source of these layers is in a belt of transverse crevassing above a bend in the glacier, below which they resemble the arcuate foliations observed in other glaciers. This layering then would have been rotated as a result of differential flow into a near horizontal attitude. The folded layers may represent an older foliation, while the more intense folding towards the western margin can be explained by the greater longitudinal compression to be expected on the inside of the bend, followed by passive rotation in the vertical plane in the straight part of the glacier. It must be added, however, that the relative ages could not be elucidated with certainty in the field and these conclusions can only be regarded as tentative.

\section{Discussion}

Each of the glaciers described above is relatively simple in shape, yet the structures are complex in detail, indicating that flow on a small scale is far from homogeneous. However, these glaciers have certain features in common which may be applicable to other glaciers. First, the shallow synclinal structure of generally discontinuous layering, displayed in the cliffs, probably represent cross-sections through arcuate foliations in their final attitudes. Occasionally, the layering is sufficiently continuous to have the appearance of stratification with which it must not be confused. Although these structures are easily seen in the vertical profiles they are unclear at the glacier surface near the snout, because of their low dip, unless the ice surface itself is steeply graded. Many glaciers have an arcuate foliation, apparently formed in or below an ice fall or an area of extensive transverse crevassing (e.g. Schwarzacher and Untersteiner, I953; Allen and others, I960; Ragan, 1969), but the exact mode of formation of this structure is still uncertain, and further studies are being made at Griesgletscher 
with this in mind. Secondly, the development of small folds with axial planes sub-parallel to the arcuate foliation is a characteristic feature of these glaciers. In the case of Vadrec da l'Albigna and Griesgletscher, the folded layers seem to represent an early longitudinal foliation; other alternatives for the Oberaargletscher might be stratification or crevasse traces. Thirdly, each of the three glaciers has a longitudinal foliation which is clearly visible at the surface near the snout. A question we might ask is: "Does foliation form at depth?" Meier ( 1960 , p. 6o), following observations on Saskatchewan Glacier, Alberta, believed that it did not, and clearly its disappearance down-glacier as the deeper ice is exposed supports this view. On the other hand, foliation at depth has been described, for example, by Kamb (1964, p. 363-64) and Lliboutry (1964-65, Tom. 2, p. 61 $3-14)$. Vallon and others (1976, p. 18-19) also refer to a "foliation" at depth, but these authors use the term in a different sense from other workers, in that they are referring to stratified ice. In the Swiss glaciers we have a range of situations. In the cliff of Oberaargletscher there is no sign of the longitudinal foliation penetrating to any depth; in Griesgletscher parts of the cliff reveal this structure faintly; while in Vadrec da l'Albigna it is well developed, even close to the base of the glacier in places. In the light of these observations, and of the fact that arcuate foliation appears at the snout (albeit sometimes faintly), it is likely that, although longitudinal foliation may not be visible, it is still present at depth. The important point, then, is that differential weathering of ice types plays a major role in enhancing the structure. Often one sees evidence of this in a crevasse wall. At the top of the wall, where the degree of weathering is greatest, the foliation is clearly visible. The transition to unweathered ice below is accompanied by an apparent weakening of the structure, but close observation reveals that there is segregation of ice types also at depth. Detailed studies of the structures and fabric in the cliff sections of glaciers, especially after a recent fall of ice, should throw some light on the varying amount of deformation between the surface and the bed but, unfortunately, such studies would be rather hazardous.

\section{Acknowledgements}

Thanks are due to Dr A. G. Milnes for advice in the field and comments on the manuscript. Financial support from the Zentenarfond of the Eidg. Technische Hochschule (Projekt Nr I89) is gratefully acknowledged.

\section{MS. received 24 November 1976 and in revised form 28 February 1977}

\section{REFERENGES}

Allen, C. R., and others. 196o. Structure of the lower Blue Glacier, Washington, [by] C. R. Allen, W. B. Kamb, M. F. Meier and R. P. Sharp. Fournal of Geology, Vol. 68, No. 6, p. 6oi-25.

Anderton, P. W. 1973. Structural glaciology of a glacier confluence, Kaskawulsh Glacier, Yukon Territory, Canada. Ohio State University. Institute of Polar Studies. Report No. 26.

Hambrey, M. J. 1977. Foliation, minor folds and strain in glacier ice. Tectonophysics, Vol. 39, Nos. 1-3, p. 397-416.

Hambrey, M. J., and Milnes, A. G. 1975. Boudinage in glacier ice-some examples. Fournal of Glaciology, Vol. I4, No. 72, p. $3^{8} 3-93$.

Kamb, W. B. 1964. Glacier geophysics. Science, Vol. I46, No. 3643 , p. $353-65$.

Lliboutry, L. A. $1964-65$. Traité de glaciologie. Paris, Masson et Cie. 2 vols. Paper $35 \mathrm{I}$.

Nye, J. F. 1952. The mechanics of glacier flow. Fournal of Glaciology, Vol. 2, No. 12, p. 82-93.

Ragan, D. M. ig69. Structures at the base of an icefall. Journal of Geology, Vol. 77, No. 6, p. 647-67.

Rutter, N. W. 1965. Foliation pattern of Gulkana Glacier, Alaska Range, Alaska. Fournal of Glaciology, Vol. 5, No. 4 I, p. 711 - 18.

Schwarzacher, W., and Untersteiner, N. 1953. Zum Problem der Bänderung des Gletschereises. Sitzungsberichte der Österreichischen Akademie der Wissenschaften. Mathematisch-naturwissenschaftliche Klasse, Abt. 2A, Bd. I62, Ht. 1-4, p. I I I-45.

Taylor, L. D. I962. Ice structures, Burroughs Glacier, south-east Alaska. Ohio State University. Institute of Polar Studies. Report No. 3 .

Vallon, M., and others. 1976. Study of an ice core to the bedrock in the accumulation zone of an alpine glacier, by M,Vallon, J.-R. Petit and B. Fabre. Journal of Glaciology, Vol. 17, No. 75, p. 13-28. 